\title{
“EXPLOITATION CREEP” AND DEVELOPMENT: A RESPONSE TO JANIE CHUANG
}

\author{
Aziza Ahmed*
}

In her article Exploitation Creep and the Unmaking of Human Trafficking Law, ${ }^{1}$ Janie Chuang insightfully describes transformations in the discourse on trafficking as it shifted from sex trafficking to human trafficking, and as human trafficking came to be understood as forced labor, and now modern day slavery. With each of these transformations, the United States government, self-anointed "global sheriff"2 of anti-trafficking efforts, deepened its emphasis on a prosecution-oriented strategy focused on individual perpetrator accountability. As an alternative trajectory, Chuang identifies and convincingly argues for a labor-rights approach that takes into consideration the structural causes of exploitation in the labor market, including poverty, unemployment, discrimination, and conflict.

In this invited response to Chuang's article, I examine how the carceral "modern day slavery" (MDS) abolitionist feminist project concerned with sex-trafficking travelled with a larger set of neoliberal prescriptions for development, including efforts to address violence against women as a means to promote women's participation in markets. Alongside Chuang and other feminist scholars who seek to decenter the criminal law as a solution to women's equality, ${ }^{3}$ I argue that this carceral approach to sex-trafficking undermines a broader set of structural reforms that are more effective than carceral measures in addressing the material needs of trafficked people as well as in lessening the likelihood of being trafficked. ${ }^{4}$

Carceral MDS abolitionist feminist ideas entered the broader development discourse in part due to a growing attention to the issue of violence against women as a barrier to women's participation as economic actors. Initially ignored in Western economic development prescriptions, women became increasingly integral to new

* Associate Professor of Law at Northeastern University School of Law. Many thanks to Benedict Kingsbury and Karen Knop for inviting me to write this response. I am indebted to Karen Knop, Libby Adler, and Jason Jackson for helpful feedback on earlier drafts.

Originally published online 11 June 2015.

${ }^{1}$ Janie Chuang, Exploitation Creep and the Unmaking of Human Trafficking Law, 108 AJIL 610 (2014) [hereinafter Chuang, Exploitation Creep].

2 Janie Chuang, The United States as Global Sheriff: Using Unilateral Sanctions to Combat Human Trafficking, 27 MiCH. L. REV. 437 (2006); Chuang, Exploitation Creep, supra note 1.

${ }^{3}$ Feminist scholars critical of the carceral response to women's rights include Leigh Goodmark, Autonomy Feminism: An Anti-Essentialist Critique of Mandatory Interventions in Domestic Violence Cases, 31 FLA. ST. U. L. REV. 1 (2009); Donna Coker, Shifting Power for Battered Women: Law, Material Resources, and Poor Women of Color, 33 U.C. DAVIS L. REv. 1009 (2000); Aya Grueber, The Feminist War on Crime, 97 IOWA L. REv. 741 (2007). For a description of the feminist turn to criminal law on issues of sexual violence see Karen Engle, Feminism and its (Dis)Contents: Criminalizing Wartime Rape in Boznia and Herzogovina, 99 AJIL 778 (2005); Elizabeth Bernstein, Carceral politics as gender justice? The "traffic in women" and neoliberal circuits of crime, sex, and rights, 41 THEORY \& SOC'Y. 233 (2012).

${ }^{4}$ In this comment, I am largely discussing sex trafficking, which raises issues of violence and exploitation distinct from those associated with sex work. In the sex-work context, the labor-rights frame offers many possibilities for rethinking violence and exploitation. 
development models as disenchantment with the neoliberal ${ }^{5}$ underpinnings of the Washington Consensus development model grew. By the mid-1990s, the ongoing failure of the Washington Consensus ${ }^{6}$ to bring economic growth and stability brought renewed attention to what law professor Kerry Rittich calls "second-generation" reforms. These reforms shifted from a narrow economic focus to a broader consideration of the "social, structural, and human dimensions" of development ${ }^{7}$ including gender, health, and education. Already identified in the context of human rights, ${ }^{8}$ and encouraged by economists including Amartya Sen, these second-generation reforms drove development agencies to look beyond their macroeconomic and financial agenda. ${ }^{9}$ It is important to note, however, that the inclusion of second-generation concerns did not pose a fundamental challenge to core neoliberal prescriptions. Instead, social and structural concerns were embedded in the larger neoliberal development paradigm pushed by the International Financial Institutions.

In keeping with this new development agenda, international institutions began to emphasize the importance of addressing violence against women as a priority not only for women's safety and well-being but also for development. As articulated by the World Health Organization:

Violence is a major obstacle to development. Violence against women in particular hinders progress in achieving development targets. Despite the growing recognition of violence against women as a public health and human rights concern, and of the obstacle it poses for development, this type of violence continues to have an unjustifiably low priority on the international development agenda and in planning, programming and budgeting. ${ }^{10}$

The report highlights trafficking as one aspect of violence against women. UN Women articulates a similar concern in calling for a Millennium Development Goal (MDG) specific to violence against women:

Gender inequality and violence hamper countries' efforts to reduce poverty. Women and girls are half of the human capital available to reduce poverty and achieve development. Yet gender-based violence undermines human rights, social stability and security, public health, women's educational and employment opportunities, and the well-being and development prospects of children and communities—all fundamental to achieving the MDGs. ${ }^{11}$

Violence against women was recast as not only an issue of physical harm but also a barrier to market participation for women and, in turn, to development for the country.

\footnotetext{
5 As defined by David Harvey, neoliberalism "proposes that human well-being can best be advanced by liberating individual entrepreneurial freedoms and skills within an institutional framework characterized by strong private property rights, free markets, and free trade." David Harvey, A Brief History of NeOliberalism 2 (2005).

${ }^{6}$ Kerry Rittich, The Future of Law and Development: Second-Generation Reforms and the Incorporation of the Social, in THE NEW LAW AND ECONOMiC DeVelopment: A Critical Appraisal (David Trubeck \& Alvaro Santos eds., 2006) [hereinafter Rittich, Second-Generation]; see also, Joseph Stiglitz, The Post Washington Consensus Consensus, The Initiative for Policy Dialogue.

${ }^{7}$ Rittich, Second-Generation, supra note 6, at 206-207 citing James Wolfensohn, World Bank Comprehensive Development Framework (Jan. 21, 1999). See also, David Kennedy, The Rule of Law, Political Choices, and Development Commonsense, in THE NEW LAW AND ECONOMIC DEVELOPMENT: A CRITICAL APPRAISAL (David Trubeck and Alvaro Santos eds., 2006).

8 In the international human rights arena, the 1979 Convention on the Elimination of All Forms of Discrimination Against Women (CEDAW) established women's equality as a priority. Convention on the Elimination of All Forms of Discrimination Against Women, Dec. 18, 1979, 1249 UNTS 13.

${ }^{9}$ Rittich, Second-Generation, supra note 6, at 209.

10 World Health Organization, Addressing Violence Against Women and Achieving the Millennium Development Goals (2005).

${ }^{11}$ United Nations Development Fund for Women (UNIFEM), The Facts: Violence Against Women and the Millennium Development Goals (emphasis added).
} 
By the 1990s, economic development practitioners also began to imagine law as important in and of itself as well as a means for development. Rule of law programs flourished. ${ }^{12}$ For feminists, this meant legislating women's rights regarding a range of issues including women's property rights, anti-discrimination, and, ending violence against women. As part of a broader struggle to change the status of women, these feminist legal reform efforts sought to redistribute resources and to bring social and cultural change. ${ }^{13}$

In the case of violence against women (VWA), however, a different feminist blueprint existed: criminal law. ${ }^{14}$ The growing feminist turn towards the criminal law in the United States provided a framework for addressing violence against women inside the broader law and development paradigm. ${ }^{15}$ Crucially, while feminists always contested whether to rely so heavily on criminal law to address VAW (including sex-trafficking), the carceral MDS feminist position predominated, and the internal feminist critique of the growing reliance on punitive models fell by the wayside.

Nothing better exemplifies the influence of the carceral MDS feminist position (alongside their allies), or lawmaking for the sake of demonstrating progress towards the rule of law, than the U.S. State Department Trafficking in Persons (TIP) Report. The annual report places countries into three tiers, according to their level of compliance with the minimum standards outlined in the Trafficking Victims Protection Act. ${ }^{16}$ The minimum standards list emphasizes punitive measures as a means to end trafficking, and these punitive measures shape the response to sex-trafficking as well. ${ }^{17}$ Chuang shows how this pressure leads to the passage of criminal laws with little concern for the structural forces that produce the conditions that allow trafficking to thrive. These conditions are often the product of the neoliberal development agenda so favored by the U.S. government (and in which, ironically, the carceral project itself is embedded).

The carceral MDS abolitionist feminist project provides legitimacy to the growing emphasis on criminalization at the cost of structural interventions. These costs have been grave and explicit. A clear example comes from the implementation of HIV programs that address some of the health needs of poor and marginalized migrant women who have a high prevalence of HIV. Carceral MDS feminists accused HIV organizations that were working to make transacting sex safer of engaging in trafficking. This advocacy resulted in the closure of HIV interventions that largely benefitted women and girls. In other words, carceral MDS feminists worked to preserve their ideological and punitive project at the cost of a structural solution. ${ }^{18}$

A growing legal and sociological literature connecting the rise of neoliberalism with the growth of criminal law helps explain why a prosecution-based approach dominates the response to violence against women. Legal scholar Bernard Harcourt argues that our increasingly punitive society is made possible by the ideology of the free market, a sphere where state intervention must be limited, while in the penal sphere it is seen as legitimate

12 David Trubeck and Alvaro Santos, An Introduction: the third moment in law and development theory and the emergence of a new critical practice, in The New Law and Economic Development: A Critical Appraisal 1 (David Trubeck \& Alvaro Santos eds., 2006).

13 See, e.g., Bina Agarwal, Gender and Command Over Property: A Critical Gap in in Economic Analysis and Policy in South Asia, 22 WORLD DEV. 1455 (1994).

14 See Deborah Weisman, The Politics of Pretext: VAWA Goes Global, CUNY L. Rev. VAWA @ 20 (Dec. 6, 2014); See Patricia Erwin, Exporting U.S. Domestic Violence Reforms: An Analysis of Human Rights Frameworks and U.S. "Best Practices", 1 FEMINIST CRIMINOLOGY 188 (2006); See Leigh Goodmark, Introduction in COMPARATIVE PERSPECTIVES ON GENDER VIOLENCE: LessONS FROM EFFORTS WORLDWIDE (Rashmi Goel \& Leigh Goodmark eds. 2015); See Allegra M. McLeod, Exporting U.S. Criminal Justice, 29 YALE L. \& POL’Y. REv. 83 (2010) (discussing the export of U.S. criminal law frameworks).

${ }^{15} \underline{I d}$.

${ }^{16}$ For a full description of the tiers see United States State Department, TrafFicking in Persons Report 2014.

${ }^{17}$ For an in-depth review of trafficking indicators see Anne T. Gallagher \& Janie Chuang, The Use of Indicators to Measure Government Responses to Human Trafficking, in GOVERNANCE BY INDICATORS (Kevin E. Davis et al. eds. 2012).

${ }^{18}$ For one example of how abolitionist feminist activism aided in closing HIV services for sex workers in Cambodia, see, Joanna Busza, Prostitution and the Politics of HIV Prevention in Cambodia: A Historical Case Study, 15 STUD. GENDER \& SeXuALITY 49 (2014). 
to increase state regulation. ${ }^{19}$ Extending Harcourt's argument to the discussion of women and development, we see that neoliberalism, the very ideology that seeks to encourage women's unfettered access to the market as the solution to their inequality, underpins the carceral and punitive response. Carceral MDS feminism prioritizes a particular conception of equality, one that requires the punishment of men's bad behavior to enable women to participate freely in markets. ${ }^{20}$ Importantly, this carceral MDS feminist logic fits into both the ongoing push towards neoliberal-oriented development projects and the rise and exportation of the U.S. criminal justice model. ${ }^{21}$

Exporting the carceral response to sex-trafficking emphasizes what is now understood to be a widely disputed and problematic means of addressing the challenges facing poor women and men living precarious lives. In the United States this is spoken of as mass incarceration, and although the vocabulary is lacking, the exportation of a punitive response and corresponding incarceration is made evident not least through the U.S. government driven anti-trafficking crime and punishment model. The current carceral MDS feminist response ignores how punitive measures produce massive inequality rather than generate a sense of resilience and capacity amongst individuals and communities.

Activists and advocates concerned about sex trafficking should take heed of Chuang's thought-provoking argument that we should lean towards structural solutions rather than individual perpetrator based accountability. Instead of emphasizing a crime and punishment agenda, we should consider the factors that make individuals vulnerable to exploitation. Further, we should interrogate how the market-based logic of development, even when pitched in terms of freedom for women, contributes to the rise of crime and punishment measures. For feminists concerned about the movement of carceral projects on the back of a neoliberal development agenda, the answer may lie in excavating a feminist-specific resistance to the carceral mode of engagement, and developing a broader vision of redistribution.

19 Bernard Harcourt, The Illusion of Free Markets: Punishment and the Myth of Natural Order (2012).

20 This may also explain, in part, why the feminists who critique carceral responses were less successful than those who have supported punitive responses to addressing violence against women, including sex trafficking.

${ }^{21}$ McLeod, supra note 14, at 111-112 (discussing the focus on anti-trafficking efforts in the context of exporting criminal law generally). 